SCHREK KATALIN

\title{
EGY ÉV A SZLÁV TÖRTÉNETI TANULMÁNYOK JEGYÉBEN - A CANADIAN-AMERICAN SLAVIC STUDIES 2019-ES ÉVFOLYAMÁNAK BEMUTATÁSA
}

\section{AN OVERVIEW OF A YEAR IN THE FIELD OF SLAVIC HISTORICAL STUDIES - AN INTRODUCTION TO THE 2019 ISSUES OF CANADIAN-AMERICAN SLAVIC STUDIES}

Canadian-American Slavic Studies (hereinafter CASS) published four impressive and interesting volumes in 2019 related to Russian and Soviet historical research. Two of them, entitled New Approaches to the Opposition to Stalin, focused on the current results of international cooperation between the members of the Association for Slavic, East European and Eurasian Studies (ASEES) and the British Study Group on the Russian Revolution. The outcomes of this joint venture were first presented at a symposium at the University of Texas in 2016 were eventually published in the CASS volume no. 1-2 in 2019. These volumes contained altogether eight articles with different kinds of historical approaches to the interpretation and explanation of the 1920s-1950s Soviet Era. The second volume (no. 3), Contact, Conflict, and Crisis in Eastern Christianity, dealt with questions concerning the relationship faced by the Russian State and the Orthodox Church from sixteenth century to modern times and the challenges of Russian and American Orthodox communities throughout the centuries. This volume enjoyed institutional support from the Association for the Study of Eastern Christian History and Culture (ASEC). And finally, the fourth volume (no. 4) is a miscellaneous one, which represents different types of research fields. The present article endeavours to highlight the main contemporary trends in modern research on Russia and the Soviet Union, and to draw up a qualitative and quantitative analysis of the said volumes.

Keywords: Canadian-American Slavic Studies, Stalin Opposition, Orthodox Church, New Historical Perspectives, International Corporations

Katalin Schrek - Ph.D., Senior Lecturer, Institute of History, Department of World History, University of Debrecen (Hungary, Debrecen, 4032 Egyetem tér 1.).

E-mail: schrek.katalin@arts.unideb.hu

ORCID: https://orcid.org/0000-0002-8601-6382 DOI: 10.38210/RUSTUDH.2020.2.10 
A Canadian-American Slavic Studies 1969 óta - jelenleg a Brill kiadásában megjelenő folyóirat, amelynek alapvető célja, hogy tudományos fórumot és egyben megjelenést biztositson elsősorban a szláv tanulmányokkal foglalkozó kutatóknak. Ugyanakkor a nevével fémjelzett tematikus kereteken túlmutatva alapvetően a Kelet-Európával (nem csak szláv kontextusban) kapcsolatos új kutatási eredmények publikálására is lehetőséget ad. Tudományágak tekintetében széles körü reprezentációval bír, a megjelentetett munkák között történet- és irodalomtudományi, kultúra- és müvelődéstörténeti, politológiai és szociológiai irányú megközelítések, elemzések sorakoznak fel angol, német, orosz és francia nyelven. Nemzetközi szerkesztőbizottságában nagy arányban vannak a kutatói szféra angolszász képviselői', ezen belül is elsősorban az amerikai intézmények jelenléte dominál. Emellett azonban a folyóirat nemzetközi jellegét és a kutatótársadalomba való integráltságát mutatja a fontosabb európai műhelyek (angol, német, francia, orosz és magyar!) kutatóinak bevonása a folyóirat szerkesztésébe. ${ }^{2}$

A folyóirat vizsgálat tárgyává tett számai 2019-ben láttak napvilágot, összesen három kötetben. A kiadványokban érvényesített szerkesztési elvek és nézőpontok eltérőek voltak, amelyeket elsősorban a megjelent tanulmányok jellege határozott meg. Az első három szám (2019/1-2. és 2019/3.) egy-egy koherens egészet alkotó tematikus, míg a harmadik (2019/4.) egy tematikai megkötöttségektől mentes, vegyes kötet. Mindkettőnek megvan a maga előnye. Az első két szám konkrét történeti problémák részterületeinek mélyelemzéseit nyújtja, s a részletektől haladunk a nagy egész átfogóbb megértése felé, míg utóbbi adott korok adott kutatási területeibe nyújt rövid betekintést. A Canadian-American Slavic Studies 2019. évi számainak bemutatásakor a kvantitatív elemzés és a tartalmi ismertetés szempontjait ötvözzük. Úgy véljük, a folyóirat munkásságának összetett bemutatásához mindkettőre szükség van, mivel a modern - elsősorban statisztikai szemléletű - megközelítés lehetőséget ad a folyóirat kutatói tudományos közegben való helyének, szerepének, beágyazottságának feltárására és a folyóirat alaposabb megismerésére. Emellett a tartalmi bemutatás révén

1 Néhány példa a teljesség igénye nélkül: University College London, University of Texas, UCLA, University of Illinois. URL: https://brill.com/view/journals/css/css-overview. xml?contents=About (Hozzáférés: 2020. október 30.)

2 Eötvös Loránd Tudományegyetem, Orosz Tudományos Akadémia, University College London, Westminster College, Ludwig-Maximilians-Universität, Université de ParisSorbonne, Université Notre Dame. 
segítséget és kiindulási pontot biztosíthatunk a hazai olvasóközönségnek az új kutatási trendek felvázolásával.

A Canadian-American Slavic Studies 2019. évi kiadványainak szerzőire vonatkozó adatokat áttekintve az első szempontunk a férfi és a női kutatók egymáshoz viszonyított és folyóiratszámokra lebontott arányának meghatározása volt. Eltérő jellegü aránytalanságot tapasztalhatunk az első (2019/1-2.) kötetben ahol a publikációk 37,5\%-a köthető női szerzőkhöz, továbbá a 2019/3. számban, ahol szintén a férfi kutatók javára dől el a mérleg nyelve 55,5\%-kal. A 2019/4. szám ugyanakkor a nemek arányát tekintve egészen kiegyensúlyozott, mivel itt a női és férfi kutatók száma fele-fele arányban oszlott meg.

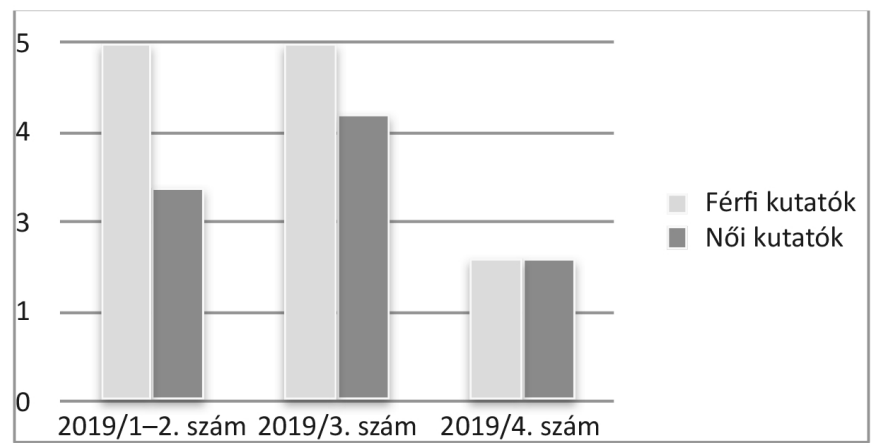

1. ábra

A férfi és női kutatók aránya a folyóiratban publikáló szerzők számát tekintve (folyóiratszám/fö)

Hasonlóképpen érdemes arra is kitérnünk, hogy a tavalyi évben publikáló szerzők közül hányan rendelkeztek tudományos fokozattal, és volt-e olyan szerző, aki nem rendelkezett PhD- vagy kandidátusi minősítéssel. E tekintetben a Canadian-American Slavic Studies egyetlen egy kivételt leszámítva teljesen egységes képet mutatott. A 2019/1-2. és a 2019/4. szám szerzői (nemtől függetlenül) mindannyian rendelkeztek tudományos fokozattal, míg a 2019/3. szám egy szerzőjének tudományos értekezése már folyamatban volt. 


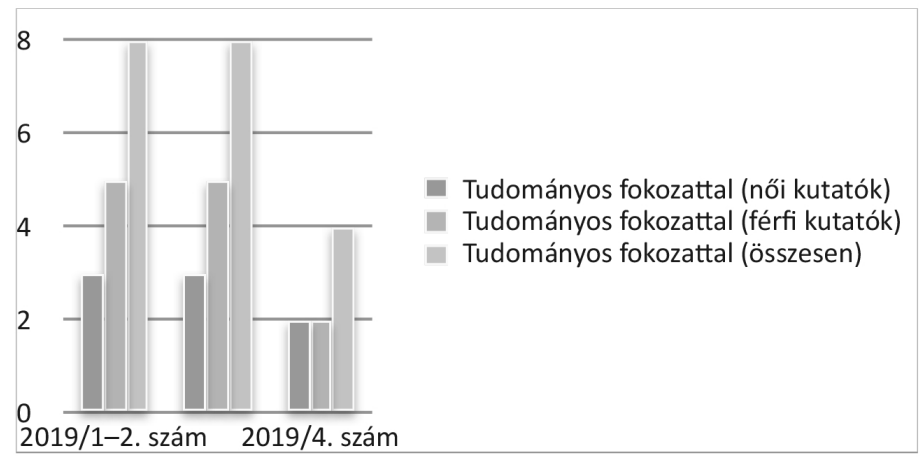

2. ábra

Tudományos fokozattal rendelkezők

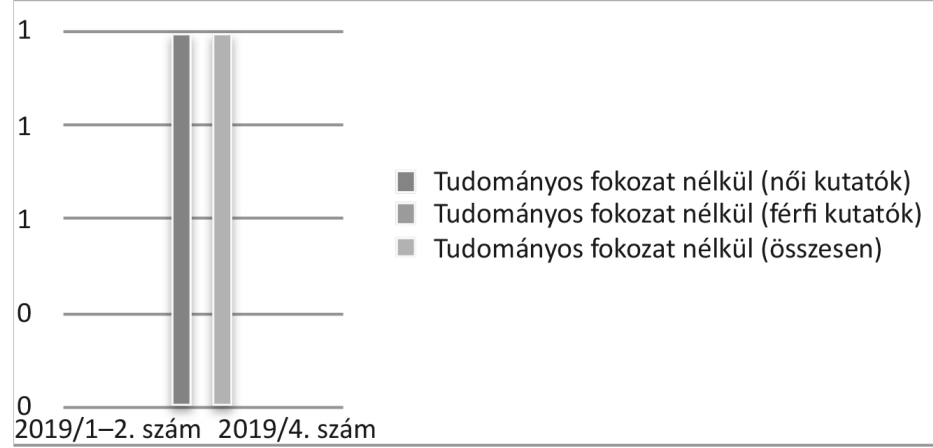

3. ábra

Tudományos fokozattal nem rendelkezők

Szintén közös jellemző jegy az intézményi kötődés. Minimálisra tehető azon szerzők száma, akik a megjelenés idején semmilyen felsőoktatási- vagy kutatói intézményhez sem kapcsolódtak közvetlenül. Persze, ez a magállapítás kizárólag a munkaügyi státuszt tükrözi vissza, és nem ad képet az ettől függetlenül akár intézményesült kereteken belül is meglévő aktív szakmai kapcsolatokról. A szerzők affiliációjának vizsgálata során egy erős, 85\%-os átlag jött ki, vagyis a publikáló gárda jelentős része egy-egy felsőoktatási vagy kutatási intézményben folytatta munkáját, és mindössze három olyan szerző került be a kötetekbe, aki függetlenül, intézményi háttér nélkül végezte az adott periódusban kutatásait (4. számú ábra). Érdekes kiegészítő 
információ lehet, hogy a 2019/1-2. és 3. számnak az intézményi kötődés szempontjából releváns szerzői kivétel nélkül mind felsőoktatási intézményekben voltak foglalkoztatva, addig a 2019/4. számban ugyanez az arány már 50-50\%-ban oszlott meg a felsőoktatási intézmények és más kutatóintézmények ${ }^{3}$ között (5. számú ábra). Ha pedig mindehhez hozzávesszük a regionális szempontot, vagyis az intézményi kötődés országokra történő szétbontását, akkor két nagy terület válik dominánssá, az Egyesült Államok (és kis részben Nagy-Britannia), valamint Oroszország. A CanadianAmerican Slavic Studies szerzői a 2019-es évben (a független szerzőket nem számolva) kizárólag ezen országok oktatási-kutatási műhelyeiből kerültek ki (6. számú ábra). ${ }^{4}$

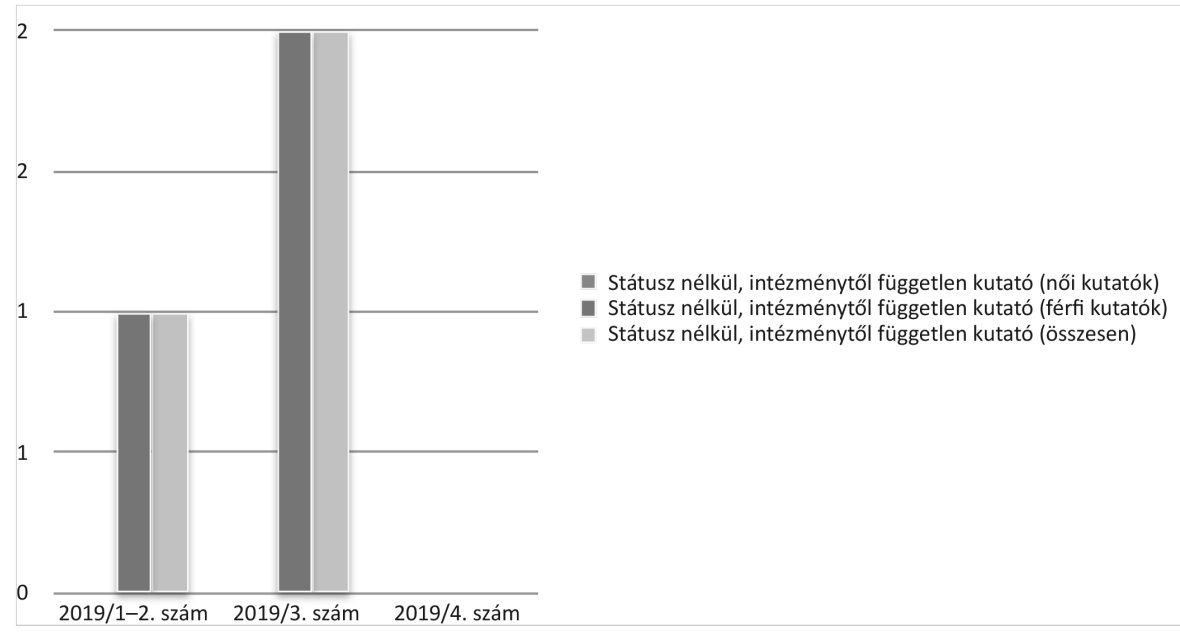

4. ábra

Intézményi státusz nélkül szerzők

3 Elsősorban az Orosz Tudományos Akadémia hálózata.

4 A négy független szerző is az Egyesült Államokhoz köthető. 


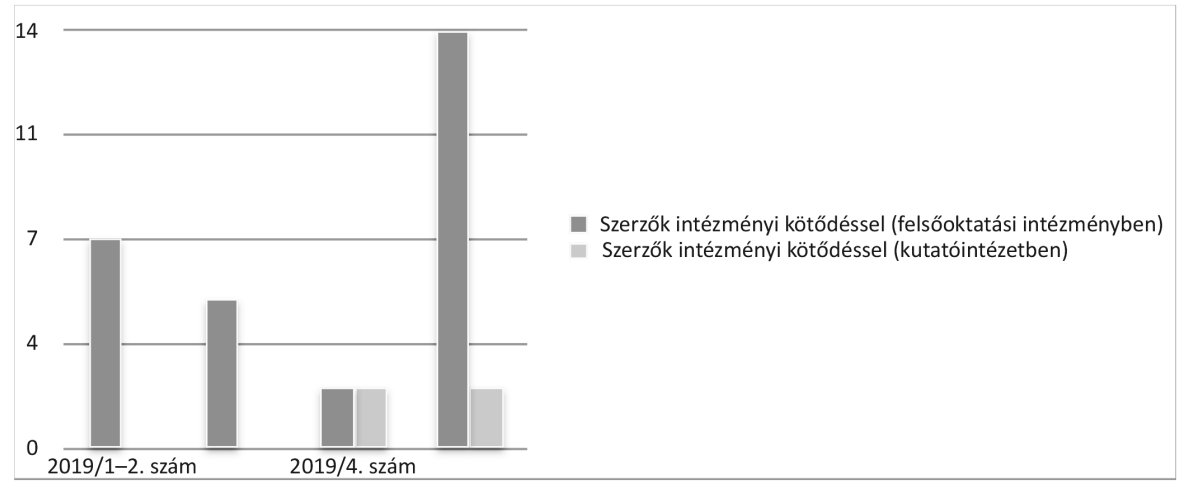

5. ábra

Intézményhez való kötődés típusa és arányai

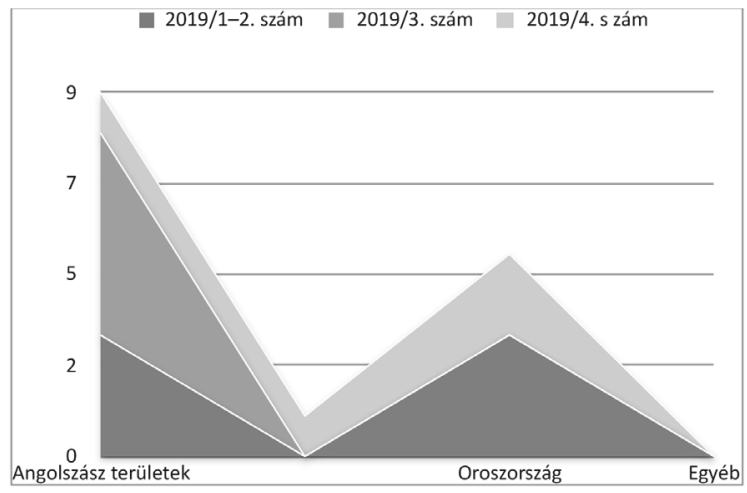

6. ábra

Intézményi kötődés regionális megoszlásban

A szerzők intézményen belüli státusza változatos képet mutat. A felsőoktatási intézményi és kutatóintézményi pozíciók alapján a docensek/tudományos munkatársak aránya a legszámottevőbb, ők a 2019. év mindhárom megjelenő számában jelentős többségben voltak, míg az adjunktusok és a professzorok/tudományos főmunkatársak számaránya lényegében azonosan visszafogottnak tekinthető (az összlétszám és nem pedig az adott folyóiratszámon belüli arányok relációjában). Ami feltűnő lehet, az a tanársegédek csoportjának teljes hiánya, de ha figyelembe vesszük a folyóirat nemzetközi rangját, valamint a tudományos fokozatnak a lényegében kötelező alapfeltételként való meglétét, akkor ez a jelenség teljesen természetes, és igazodik a nemzetközi szaktudományos folyóiratok trendjéhez. 


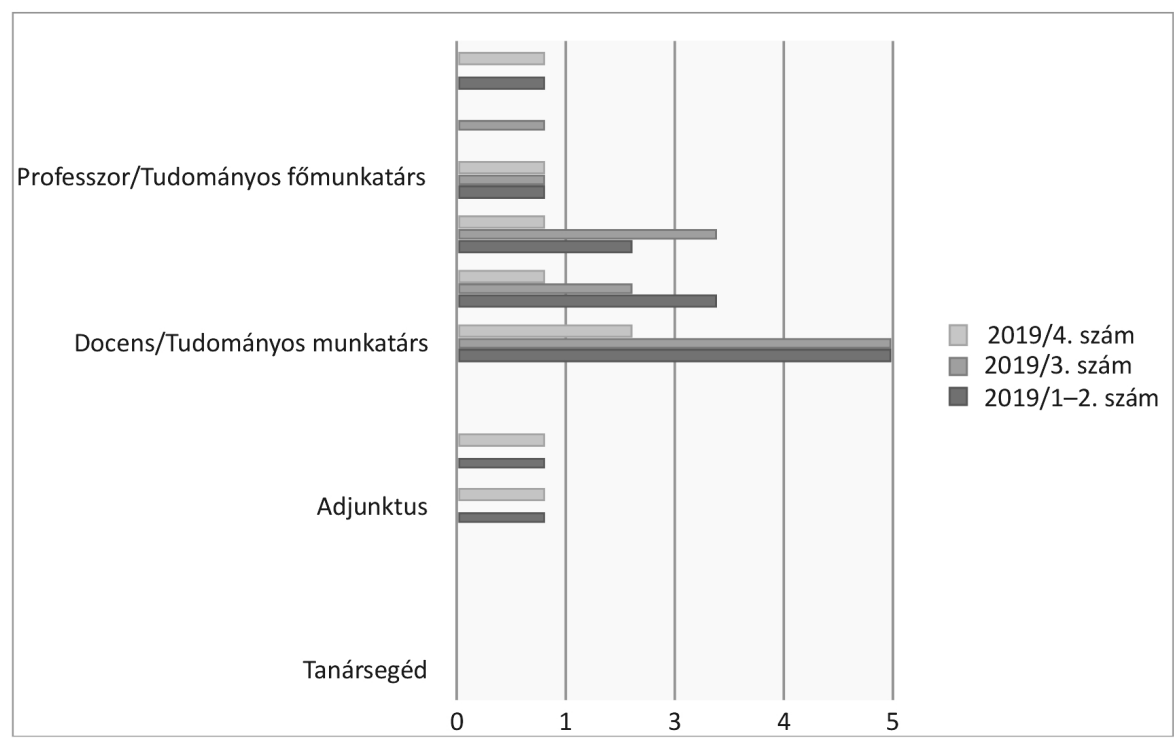

7. ábra

Szerzők aránya intézményi státusz alapján

Tudománymetriai adatok alapján a Canadian-American Slavic Studies általunk vizsgált tárgyévre vonatkozó számairól egyelőre nem rendelkezünk részletes adatokkal, ami az eltelt idő rövidségével indokolható. Néhány statisztikai adat azonban már rendelkezésre áll. A Scimago Journal and Country Rank besorolása alapján a folyóirat 2019-ben a kulturális tanulmányok és a történettudomány témakörében egyaránt Q3-as besorolást kapott, az összesített SJR-indikátora, amely a más folyóiratok általi hivatkozások számát és a citáció forrásának elismertségét veszi alapul, jelenleg 0,118, amely az elmúlt évek összevetésében (2010-2019 közötti átlagérték $0,107)$ átlagot meghaladónak mondható. ${ }^{5}$

Ahogyan a bevezetőben korábban említettük, a Canadian-American Slavic Studies a 2019-es évben három kötettel jelentkezett a tudományos közösség számára. Az első kötet a 2019/1-2. szám A sztálini ellenzék új megközelítései címet viseli, amely egy 2016-ban a Texasi Egyetemen megtartott nemzetközi konferencia előadásainak válogatott anyagát publikálta. Az Alekszisz Pogorelszkin vendégszerkesztésében összeállított és előszavával ellátott kiadvány nem csupán a sztálini éra történeti problémáit új

5 URL: https://www.scimagojr.com/journalsearch.php?q=6000173131\&tip=sid\&clean=0 (Hozzáférés: 2020. november 29.) 
nézőpontba helyező, friss kutatási eredményeket kívánta összegezni, hanem egy formálódóban lévő nemzetközi kutatói együttműködés körvonalait és távlati terveit is felvázolta, amely a pittsburgi egyetemi központtal müködő Egyesület a Szláv, Kelet-Európai és Eurázsiai Tanulmányokért (Association for Slavic, East European and Eurasian Studies - ASEES) nevü szervezet és az Orosz Forradalom(történeti) Brit Kutatócsoport (British Study Group on Russian Revolution - BSGRR) közös kooperációjából bontakozott ki. A fö célkitüzés az volt, hogy az 1920-as évek szovjet történelmének vitás kérdéseit és ezen belül is a sztálini ellenzék vizsgálatát új perspektívába tudják helyezni.

Barbara C. Allen értekezése a munkás ellenzék helyzetével és politikai szerepvállalásával foglalkozott. Az egyik fontos kérdésfelvetése az volt, hogyan működhettek együtt a különböző társadalmi osztályok 1917 októberét követően. Különösen nehéz megítélni és utólagosan vizsgálni az úgynevezett szakértő embereknek a helyét és szerepét ebben az új politikai rendben. Ők azok, akik szaktudásukat és képzettségüket még a cári időszak intézmény rendszereiben szerezték, de olyan tudással rendelkeztek, amely a forradalmi időszakot követően is értékes volt. Alkalmazásuk még Lenin idején lehetséges volt, Sztálin időszakában ezek a személyek azonban teljes mértékben marginalizálódtak. A tanulmány azt is vizsgálja, hogyan viszonyult a szakértőkhöz a munkásellenzék. ${ }^{6}$

Viktor Viktorovics Bahtyin a voronyezsi Cionista Szervezet müködését vette górcső alá a rendelkezésre álló levéltári források tanulmányozásával. Az elemzés külön érdekessége, hogy a cionista személyek ellen az 1920as évek végén és az 1930-as évek elején folytatott vizsgálatok nyomozati anyagait tekintette át, az egyedülálló forrásbázis pedig lehetővé tette, hogy ne csupán a lefolytatott perek társadalmi-politikai hátterére világítson rá a szerző, hanem rekonstruálja a bírósági eljárások folyamatát, ami jog- és igazgatástörténeti szempontból is érdekes lehet a kutatók számára.7 A regionalizmus és klientizmus problematikáját vetette fel Calyton Black, amely fogalmakat a Zinovjev-féle leningrádi ellenzék működési mechanizmusának kontextusában vizsgálta. Black számos történetírói munkára reflektálva úgy vélte, hogy magát a szovjet rendszert egy sajátos történelemfelfogásban kell értelmezni, amely újra és újra felszínre hoz bizonyos sémákat. Ilyennek

6 Barbara C. Allen, “The Workers' Opposition and the Specialists", Canadian-American Slavic Studies 53, no. 1-2 (2019): 5-23. DOI: 10.1163/22102396-05301002

7 Виктор Викторович БАХтин, «Сионистские Организации в Воронеже По материалам архивно - следственных дел ОГпУ конца 1920-х начала 1930-х годов», CanadianAmerican Slavic Studies 53, no. 1-2 (2019): 24-49. DOI: 10.1163/22102396-05301003 
tartja például a klientúrarendszert, amely korokat átívelően a hatalomgyakorlás egyik fontos alapja. Ugyanakkor például Zinovjev pozíciója nem magyarázható egyszerűen az őt támogató emberek hűségével, magatartása pedig inkább volt a helyi társadalmi feszültségekre való regionális megnyilvánulás, mintsem a központi kormányzat ellen irányuló támadás. ${ }^{8}$

Az áprilisi tézisek interpretációját gondolta újra Lars T. Lih, aki az újrafelfegyverezés helyett a bolsevik politika felfegyverzett jellegének narrativáját bontja ki, miközben érvelésének fő alaptétele, hogy valójában nincs szakítás és nagy váltás az 1917 tavasza előtti és utáni bolsevizmus között, hanem éppen ellenkezőleg, kontinuitás tapasztalható. Lih vitatja, hogy az áprilisi tézisek cezúrát jelentettek volna a párt radikális irányba való eltolódásában, mert az egy szerves fejlődési folyamat következménye volt. ${ }^{9}$ Lars T. Lih-hez hasonlóan izgalmas és merész elemzést olvashatunk Alekszisz Pogorelszkin tollából, aki Lenin végrendeletével kapcsolatos új történeti nézőpontot konstruált, amelyben nem csupán a dokumentum keletkezésének körülményeibe és a körülötte kialakult eltérő történetírói véleményekbe nyújt betekintést, hanem abba is, hogyan hatott a testamentum az általa megnevezett személyekre. Így az elemzés eltér az elmúlt évtizedek alapvetően Sztálin-központú megközelítéseitől.10

A belső ellenzék 1925-1929 közötti tevékenységével foglalkozott Irina Takala, aki elsődleges forrásbázisként az Egyesített Állami Politikai Igazgatóság (OGPU) anyagait használta fel.11 Szintén a belső vitákra fókuszáltak Alekszandr Reznyik ${ }^{12}$ és Charters Wynn írásai. Előbbi a trockista ellenzék, utóbbi a NEP mellett kiálló Mihail Tomszkij tevékenységét dolgozta fel. Wynn tanulmányában egy kevésbé kutatott területet érint, a Politbüró és a szakszervezetek vezetőjének az új gazdaságpolitika megtartása érdekében folytatott küzdelemét, ellehetetlenítésének folyamatát mutatta be,

8 CLAYTON BLACK, “Regionalism or Clientelism? Explaining the Zinoviev-Leningrad Opposition of 1925", Canadian-American Slavic Studies 53, no. 1-2 (2019): 50-71. DOI: 10.1163/2210239605301004

9 LARS T. LIH, “A Fully Armed Historiography”, Canadian-American Slavic Studies 53, no. 1-2 (2019): 72-89. DOI: 10.1163/22102396-05301005

10 AleXIS Pogorelskin, “'Under Seven Seals': New Perspectives on Lenin Testament”, Canadian-American Slavic Studies 53, no. 1-2 (2019): 90-106. DOI: 10.1163/2210239605301006

11 IRINA TAKALA, “'Love Live Comrade Trotskii!': The Discourse on the Intra-Party Opposition in the Documents of the OGPU", Canadian-American Slavic Studies 53, no. 1-2 (2019): 121-148. DOI: $10.1163 / 22102396-05301008$

12 AleXAnder Reznik, “'Revising the Trotskyist' Opposition of the Bolshevik Party in 19231924", Canadian-American Slavic Studies 53, no. 1-2 (2019): 107-120. DOI: 10.1163/2210239605301007 
amelyet Sztálin a Komszomol szervezetén keresztül indított el, és amely a 8. Szakszervezeti Kongresszus ülésén érte el csúcspontját Lazar Kaganovics és társainak a vezetőségbe való beemelésével. ${ }^{13}$

A vizsgálat alá vont harmadik (2019/3.) szám teljesen más témakört ölel fel, és a Kapcsolódás, konfliktus és krízis a keleti kereszténységben címmel jelent meg. A publikált tanulmányok három nagyobb kronológiai egységre bonthatók: kora újkor, 19. század és 20. század. Az időrendi sorban haladó tanulmányok - az első kötethez hasonlóan - egy 2015-ben megrendezett nemzetközi konferencia előadásanyagait fogták össze, és a keleti kereszténység kutatásában rejlő lehetőségekre, új alternativákra kivántak rámutatni. Ahogyan J. Eugene Clay bevezetőjében fogalmazott, ez a kutatási terület „relative mellőzött”, ezért különösen fontos munkát végez a Társaság a Keleti Keresztény Történelem- és Kultúratudományokért (Association for the Study of Eastern Christian History and Culture - ASEC) nevü szervezet, amely összetartja az adott területek kutatóit.

Bár a kora újkor egyetlen egy tanulmánnyal némiképp alulreprezentált, Charles Halperin értekezése rendkivül izgalmas témát feszeget. Az ortodox kolostorok komoly vitákba bocsátkoztak laikusokkal, olykor pedig más kolostorokkal saját privilégiumaik megőrzése érdekében az 1530-1580as években. A vitás ügyekkel kapcsolatban fennmaradt források alapján Halperin különböző szempontok szerint vizsgálta az ügyeket, az egyik ilyen a regionális elhelyezkedés vagy éppen az elfajuló vita (vagy éppen erőszak) mértéke. ${ }^{14}$ Már a 19. század vallásügyi kérdéseire tereli a figyelmet Barbara Skinner munkája, amely az Orosz Birodalomba integrált belorusz területek nagyszámú görögkatolikusának helyzetét helyezi a középpontba. Az orosz kormányzat és a pravoszláv egyház közös igénye volt a „keleti” katolikusok helyzetének rendezése. Az elsődleges cél az orosz államegyház kereteibe történő beolvasztás volt, amelyet adott időszakokban más-más módszerrel kivántak végrehajtani. Ezeket az alternativákat és az 1839-re végrehajtott áttérés folyamatát mutatta be a szerző.15

13 Charters Wynn, "NEP's Last Stand: Mikhail Tomsky and the Eighth Trade Union Congress", Canadian-American Slavic Studies 53, no. 1-2 (2019): 149-175. DOI: 10.1163/2210239605301009

14 ChARLES J. HALPERIN, "Neighbours are Not Always Friendly: Conflicts between Muscovite Monasteries and Their Neighbours during the Reign of Ivan IV", Canadian-American Slavic Studies 53, no. 3 (2019): 219-245. DOI: 10.1163/22102396-05303002

15 Barbara SkInNer, "Orthodox Missions to the 'Ancient Orthodox' Lands in Belarus and the 1839 Uniate Conversion", Canadian-American Slavic Studies 53, no. 3 (2019): 246-262. DOI: 10.1163/22102396-05303003 
A cár-pápaság mítoszának feltárására vállalkozott Heather Bailey, aki a francia katolikusok és az orosz egyháziak elvi vitájának egy érdekes szegmensét mutatta be. Az elemzett nézetekben az ortodox egyház az autokrata orosz állam és az uralkodó elnyomása alatt áll, ami már-már egyfajta keleti „pápizmus" meglétét jelzi a francia katolikus bírálók számára. A retorikailag is nagyon impressziv érvelés pedig fontos szempont volt az 1850-es évek végén, amikor Franciaország szorosabbra kívánta füzni kapcsolatait a Pápai Állammal. ${ }^{16}$

Egy vállalkozás történetének vallástörténeti irányultságára helyezte a hangsúlyt Lucien Frary, aki az Orosz Gőzhajózási Társaság széleskörü tevékenységét vizsgálta. Az 1850-es évek végén alapított cég nem csupán a fekete-tengeri kereskedelem és a térségben történő kapcsolattartás, valamint a postai-szállítmányozási funkciói révén vált meghatározóvá, hanem az 1860-1880-as évektől az orosz hivek (és ezen belül is elsősorban a parasztság) Szentföldre történő zarándoklatában is fontos szerepet játszott, hozzájárulva ezzel az ortodoxok és a helyi keresztény közösségek kapcsolatainak építéséhez. ${ }^{17}$

Carol Dockham írásában az ortodox egyház bolsevik hatalomátvételt követő történetének viszontagságait mutatta be az 1925 előtti és utáni időszakban, aminek egyik megnyilvánulási formája a liturgikus szokások átalakításának kikényszerítése volt Tyihon pátriárka halálát követően. ${ }^{18}$ Egy rendkivül spirituális kapcsolat személyes levelezésen keresztüli rekonstruálására vállalkozott Christopher D. L. Johnson, aki lényegében egy ortodox hitre való áttérés a történetét tárja elénk, G. E. H. Palmers és Nikon atya eszmecseréje tükrében.

Végül a kötet két amerikai vonatkozású tanulmánnyal zárul.19 Dellas Oliver Herbel az észak-amerikai ortodox közösségek helyzetét és az adott korszakokhoz kötődő problémáit, törekvéseit mutatta be a 19. század második felétől egészen napjainkig. Hangsúlyozta, hogy Alaszka Egyesült Államok

16 Heather Bailey, “Roman Catholic Polemicists, Russian Orthodox Publicists, and the TsarPope Myth in France, 1862-1842", Canadian-American Slavic Studies 53, no. 3 (2019): 263285. DOI: $10.1163 / 22102396-05303004$

17 LUCIEN Frary, "Pilgrims and Profits: The Russian Company of Steam Navigation and Trade, 1856-1914", Canadian-American Slavic Studies 53, no. 3 (2019): 286-305. DOI: 10.1163/22102396-05303005

18 CARol DochKam, "Liturgical Commemorations, Political Dissent and Religious Schism in the Russian Orthodox Church during the 1920s and 1930s", Canadian-American Slavic Studies 53, no. 1-2 (2019): 306-322. DOI: 10.1163/22102396-05303006

19 Christopher D. L. Johnson, "Epistolary Pilgrimage and Eldership in G. E. H. Palmer's Correspondence with Fr. Nikon Strandtman", Canadian-American Slavic Studies 53, no. 3 (2019): 323-341. DOI: 10.1163/22102396-05303007 
által történő megvásárlását követően a korábban kialakult helyi ortodox közösségek tagjai ragaszkodtak hitük megtartásához, a hitük melletti erős kiállás pedig alapjaiban volt jellemző az amerikai ortodox egyházra a 20. század során is, amely mind más-más szinten és fórumokon küzdött fennmaradásáért és megerősödésért. ${ }^{20}$ Ezzel szemben Amy A. Slagle tanulmánya nem elsősorban történeti jellegü, hanem inkább a vallás és a kulturális antropológia ötvözete, amelyben közvetlen interjúk és személyes források alapján elemezte a mississippi-i ortodoxok ikonok iránti tiszteletét és hagyományait. ${ }^{21}$

A Canadian-American Slavic Studies 2019-es évfolyamának utolsó száma nem illeszkedik a korábbi kiadványok szerkesztési mintájába, egy önálló, rövidebb kötetről van szó, amely négy tematikusan és kronologikusan egymástól teljesen független írást tartalmaz, ezért nem is tudunk fő irányvonalat meghatározni annak összetételében. Maguk a tanulmányok sem időrendben követik egymást, a logikai rend megőrzése érdekében azonban mi ennek megfelelően vesszük számba őket.

Szergej Bogatyrev munkája a 12-15. századi krónikákat vette alapforrásként a korabeli fejedelemlisták tanulmányozása során. Az 1100-1400-as években közölt uralkodói listák két eltérő típusaként a részletes, genealógiai leírást is tartalmazó, valamint az egyszerűbb uralkodói listákat vetette össze és elemezte nyelvi, valamint történeti szempontok alapján. ${ }^{22}$ Kora újkori témát dolgozott fel Olga E. Koseleva, aki a bojár duma intézményének, valamint a bojár ellenállás jelenségének a marxista történeti interpretációját tette vizsgálat tárgyává, és egy átfogó historiográfiai elemzést adott a kérdésben. ${ }^{23}$ Szintén kora újkori kiindulási ponttal, de évszázadokat átivelően kapunk képet az észak-kaukázusi orosz-muszlim kapcsolatokról, amelyeket Sean Pollock új források bevonásával igyekezett árnyalni. Regionális jellegű forrásfeldolgozásának eredményeképpen a szerző át szeretné

20 Dellas Oliver Herbel, “The Americanization of Orthodox Christians' Promotion of Religious Freedom", Canadian-American Slavic Studies 53, no. 3 (2019): 342-363. DOI: 10.1163/22102396-05303008

21 Amy A. SLagle, "Icons in the Lived Experience of American Orthodox Christians: A Case Study", Canadian-American Slavic Studies 53, no. 3 (2019): 364-384. DOI: 10.1163/2210239605303009

22 Sergel Bogatyrev, "Memory and Politics in the Chronicle Lists of Princes, 12th15th Centuries", Canadian-American Slavic Studies 53, no. 4 (2019): 449-488. DOI: 10.1163/22102396-05304004

23 ОЛГА Е. КошеЛЕВА, “Советские историки-марксисты о Боярской Думе и боярстве в Московском государстве", Canadian-American Slavic Studies 53, no. 4 (2019): 414-434. DOI: $10.1163 / 22102396-05304007$ 
formálni azt a hagyományos képet, miszerint kevés párbeszéd lett volna az orosz állam képviselői és a helyi népek között. Illetve felhívja a figyelmet arra, hogy a diplomáciatörténeti kutatások a régió 17-20. századi történetét illetően még igencsak hiányosak, és általában nem követik az ilyen típusú történetírói megközelítéseket. ${ }^{24}$ Végül pedig Jelena Maraszinova eszmetörténeti tanulmányát kell megemlítenünk, amely II. Katalinnak az uralkodói hatalom átörökitésével kapcsolatos szemléletét és elmélkedését vizsgálta Feofan Prokopovics Az uralkodó akaratának joga és az 1689-es Bill of Rights kontextusában. ${ }^{25}$

Összességében úgy véljük, hogy a Canadian-American Slavic Studies 2019. évi számai a szláv történeti kutatások rendkívül színes palettáját vonultatják fel, amelyek értékes szempontokat, új eredményeket nyújtanak a hazai és nemzetközi ruszisztika kutatói számára. A publikáló szerzők innovatív és olykor interdiszciplináris megközelítései pedig betekintést adnak a modern történetírói trendek alakulásába. A folyóirat 2019. évi számai ugyan nem egységes koncepció köré szerveződtek - erre talán az utóbbi évek gyakori szerkesztőváltásai hatással lehettek -, pozitivumnak tekinthető, hogy a kiadási-szerkesztési nehézségek ellenére a Canadian-American Slavic Studies meg tudta őrizni színvonalát, és továbbra is a történettudomány egyik rangos, nemzetközi periodikája maradt.

24 SeAn Pollock, "Who Spoke for Russian Muslims? Turki Letters and Russian Empire in the North Caucasus between the 17th and 20th Centuries", Canadian-American Slavic Studies 53, no. 4 (2019): 387-413. DOI: 10.1163/22102396-05304008

25 ЕЛЕНА МАРАСиновА, «Проблема наследования престола в веке: “Declaration of Rights" и “Правда воли монаршей" в бумагах Екатерины», Canadian-American Slavic Studies 53, no. 4 (2019): 435-448. DOI: 10.1163/22102396-05304005 



\section{VENDÉGROVAT \\ ГОСТЕВАЯ СТРАНИЦА \\ GUEST PAGE}


